\title{
Proctitis and herpes simplex virus in homosexual
}

\section{men}

\author{
D GOLDMEIER \\ From the Whitechapel Clinic, the London Hospital
}

SUMMARY In a study of the prevalence of rectal infection with herpes simplex virus (HSV) in a group of homosexual men the magnified appearance of the rectal mucosa correlated with isolation of the virus. HSV was isolated from rectal material from five of 77 men with proctitis of unknown cause but from none of 44 control patients without proctitis; two of four men with HSV proctitis were asymptomatic. Thus, the magnified rectal mucosal image, showing severe congestion, haemorrhage, and pus, appears to be a sensitive indicator of the presence of HSV proctitis.

\section{Introduction}

Herpes simplex virus (HSV) is a cause of urethritis in less than $1 \%$ of men with nongonococcal urethritis. ${ }^{1}$ Although studies indicate that HSV is a cause of proctitis in homosexual men $^{23}$ there are no reports of the prevalence of this infection. The present study was undertaken to estimate this in two groups of patients-those with and those without proctitis. A correlation between the magnified rectal mucosal appearance, as seen through the operating microscope, and the presence of HSV in rectal material was also attempted.

\section{Patients and methods}

All homosexual men who attended the Whitechapel Clinic at the London Hospital or the Diagnostic Clinic at Moorfields Eye Hospital between 1 July 1974 and 30 November 1975 were included in the study. Only those men who admitted to passive penorectal intercourse in the previous year were included. Full sexual and general medical histories were taken, including details of the most recent date of passive intercourse and the number of such contacts in the four weeks before initial attendance. Patients who admitted to taking antibiotics within the month before attending hospital were excluded from the trial. Details of the survey were explained to the patient, whose verbal consent was then obtained.

DIAGNOSTIC CRITERIA FOR PROCTITIS

Proctitis was defined when one or more of the following changes were visualised through an

Address for reprints: Dr D Goldmeier, Department of Genitourinary Medicine, University College Hospital, London WC1

Received for publication 13 August 1979 operating microscope using $\times 16$ and $\times 25$ magnification: (a) minimal to moderate mucosal congestion (Fig 1); (b) severe mucosal congestion (Fig 2); (c) haemorrhagic appearance (Fig 3); and (d) the presence of pus-like material in the rectum which contained at least 10 leucocytes per microscopic field $(\times 1000)$.

Patients with known ulcerative proctitis, Crohn's disease of the rectum, gonococcal or chlamydial proctitis, or an early syphilitic lesion in the anorectal area were excluded from the study.

\section{CLINICAL EVALUATION}

A full general examination was made initially. The rectal mucosa was then viewed through a metal proctoscope wth the patient lying in the left lateral position. Subsequently, a magnified image of the mucosa $(\times 6, \times 10, \times 16$, and $\times 25)$ was obtained by means of a Zeiss operating microscope (Carl Zeiss Ltd). Photographs of the area were taken using an Alpha Reflex 9F camera (Pignons, Switzerland) attached to the microscope. Any pus-like material found by such examination was removed with a sterile bacteriological loop, smeared on to a glass slide, fixed by heat, and stained by Gram's method.

Rectal material was obtained for culture for HSV by thoroughly rubbing a cotton-tipped wooden swab (Johnson and Johnson Ltd) over the rectal area in view. This swab was placed in HSV transport medium (medium 199 with Hanks balanced salt solution, bovine plasma albumin $0.5 \%$, gentamycin $50 \mathrm{mg} / \mathrm{ml}$, and mycostatin $50 \mathrm{mg} / \mathrm{ml}$ ) and stored at $4^{\circ} \mathrm{C}$ for less than 12 hours. To exclude other causes of proctitis, rectal material was obtained for culture for $N$ gonorrhoeae and Chlamydia trachomatis as previously described. ${ }^{4}$

Repeated darkfield examinations were made on 


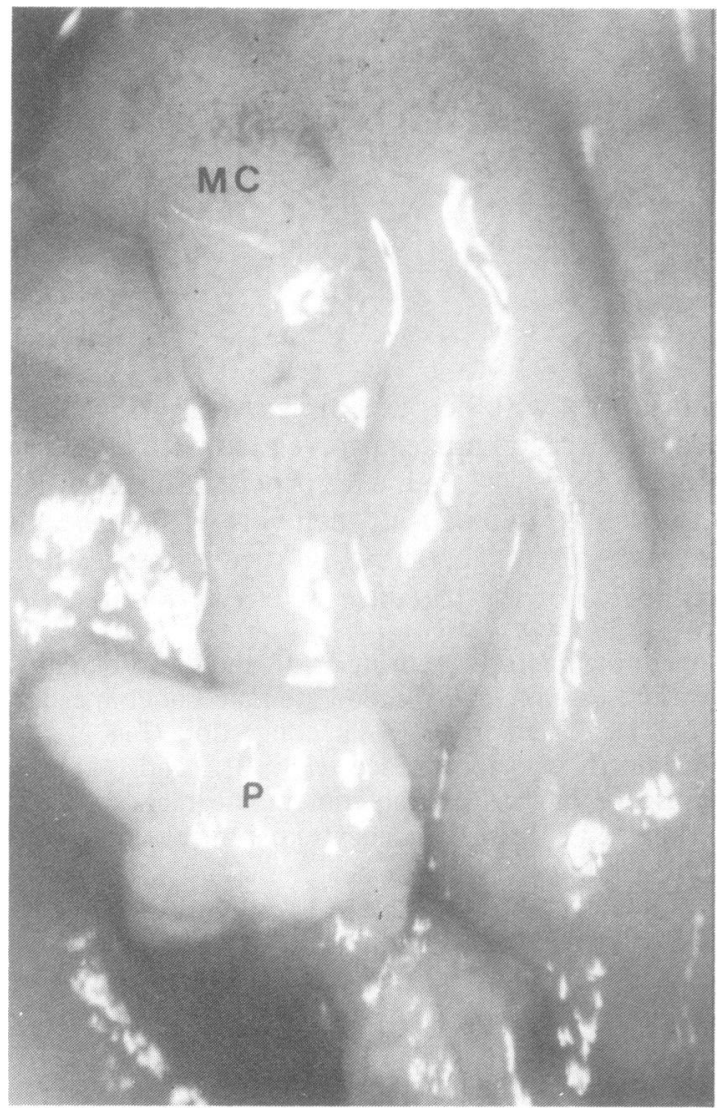

FIG 1 Photomicrograph showing minimal-to-moderate mucosal congestion $(M C)$ with pus $(P)(\times 16)$

serum from anal ulcers, if present, to exclude syphilis. The throat was then visualised and tonsillar and faucial material transferred on a cotton-tipped wooden swab for culture for HSV.

\section{LABORATORY INVESTIGATIONS}

After transportation rectal and throat material were transferred on to a monolayer of human embryonic lung cells for culture. These cells were incubated and inspected daily for seven days to exclude the presence of specific cytopathic effects of HSV. Where possible, the virus was typed according to the cellular morphology of the culture.

The method of culture of rectal material for $N$ gonorrhoeae and $C$ trachomatis has been described in detail elsewhere. ${ }^{4}$

Blood was taken at the first visit for serological tests for syphilis (automated reagin test and Reiter protein complement fixation test), and for storage of serum for later testing, using the HSV complement fixation test (HSVCFT) where rectal cultures had given positive results. Where herpetic proctitis was diagnosed, serum was tested again some weeks after the initial attendance using the HSVCFT.

STATISTICAL AND DEMOGRAPHIC DETAILS

Demographic details were obtained from all patients. Snedecor's $t$ test was used to compare mean values obtained in test and control groups.

\section{Results}

Seventy-seven patients had proctitis of unknown cause. HSV was isolated from five of these but from none of the 44 control patients who did not have proctitis. The demographic details of the two groups, which showed no obvious bias, are given in Table I. The difference between the means of the number of passive peno-rectal encounters of patients in the two groups during the four weeks before initial attendance (proctitis $2 \cdot 25$, no proctitis $1 \cdot 96$ ) was not significantly different $(\mathrm{P}>0 \cdot 05)$.

Diagnostic details for the patients with proctitis are given in Table II. The clinical pictures and laboratory

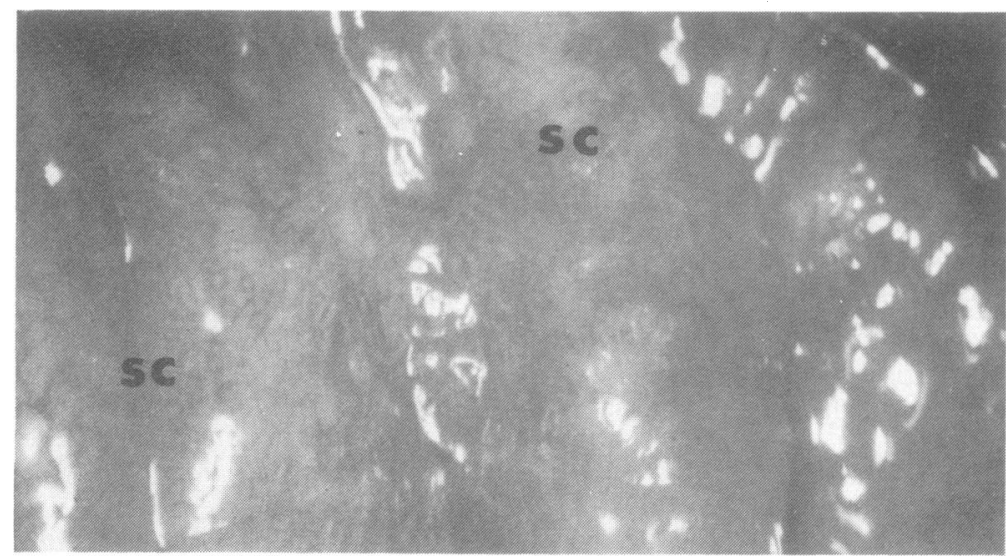

FIG 2 Photomicrograph showing severe mucosal congestion (SC) $(\times 25)$ 
TABLE I Demographic details of study and control groups

\begin{tabular}{lll}
\hline $\begin{array}{l}\text { Demographic } \\
\text { details }\end{array}$ & $\begin{array}{l}\text { With proctitis } \\
(n=77)\end{array}$ & $\begin{array}{l}\text { Without proctitis } \\
(n=44)\end{array}$ \\
\hline Mean age (years) & $32 \cdot 4$ & $31 \cdot 3$ \\
Ethnic group & & \\
Caucasian & 73 & 42 \\
$\quad$ Negroid & 3 & 2 \\
$\quad$ Indian & 1 & 0 \\
Occupation & & \\
Clerical & 16 & 11 \\
Manual/unskilled & 21 & 10 \\
Manual/skilled & 15 & 13 \\
Professional & 18 & 8 \\
Others & 7 & 2 \\
Total & 77 & 44 \\
\hline
\end{tabular}

details of the five patients with proctitis from whom HSV was obtained from rectal material are given in Tables III and IV. HSV was not grown from throat material of any of the five patients.

\section{Discussion}

HSV was grown from rectal material from five $(6 \%)$ men with proctitis. No throat isolates were obtained in these men, so that the virus presumably did not reach the rectum by a transintestinal route. This study thus estimates the prevalence of HSV in homosexual men with proctitis. HSV is known to be excreted from the cervix and vulva from asymptomatic women with previous clinically apparent HSV infections. ${ }^{5}$ Patients 4 and 5 (Table III) appeared to be asymptomatic excretors of HSV, although in the case of one of them examination with the naked eye indicated a mild proctitis. A more accurate indication of the frequency of periods of infectivity in this population would be obtained by following a cohort of such men with a known history of excreting HSV in rectal material over a period of time.

This work was also undertaken to attempt to correlate the clinical findings with positive culture results from rectal material. In none of the $\mathbf{4 4}$ patients who showed no evidence of proctitis was HSV cultured. Because only $6 \%$ of those with proctitis were infected with HSV it would seem impracticable to screen all homosexual men with proctitis for HSV. However, two of the four men with severe mucosal congestion and haemorrhagic change, noted by means of the operating microscope, were found to be excreting HSV. Similarly, two $(14 \%)$ of 14 men with severe mucosal congestion were excreting the virus. Hence, the use of the operating microscope seems to be a practicable screening technique for herpetic proctitis.

The author is grateful to the Medical Research Council for a grant to carry out this work (grant No. G 973/515/C) and to Irene Prentice for her excellent illustration. My grateful thanks are given to DrE MC Dunlop for his encouragement and help with the comments at all stages of this work; to Dr P Rodin for his invaluable advice; to the Virology Department of the London Hospital Medical College for HSV cultures; and to Mr S Goldsmith and his staff of the Whitechapel Clinic for their clinical assistance.

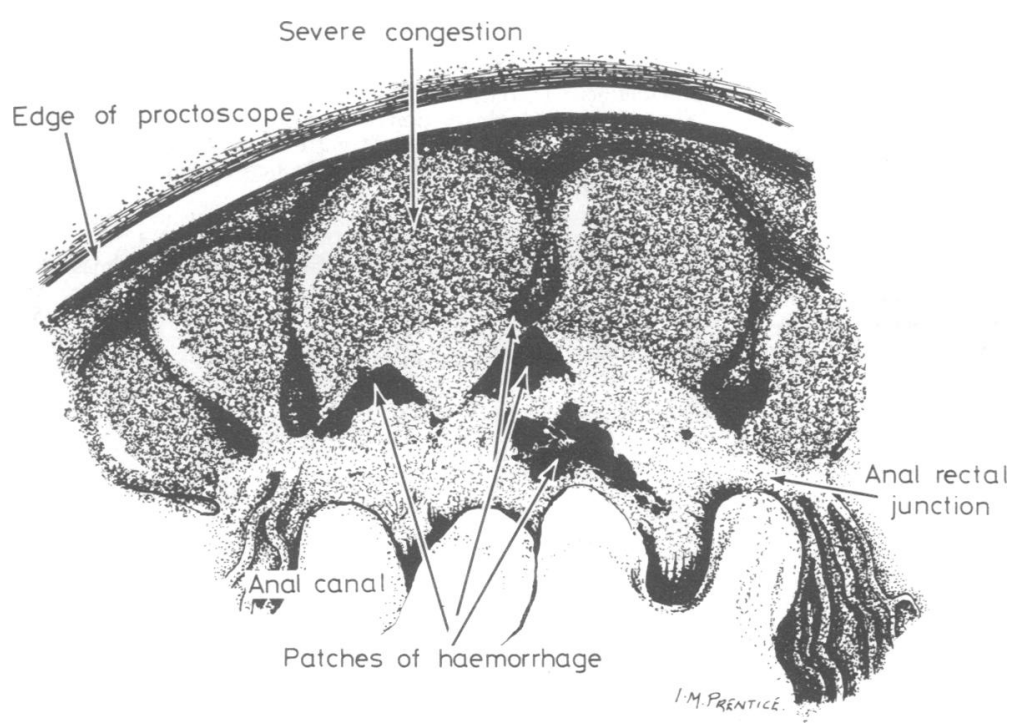

FIG 3 Illustration of anorectal area with proctitis and haemorrhagic mucosa ( $\times 16)$ 
TABLE II Microscopical appearance (× 25) of rectal mucosa in 77 men with proctitis (figures in parentheses indicate mucosal changes visible to the naked eye)

\begin{tabular}{|c|c|c|c|c|}
\hline & $\begin{array}{l}\text { Mucosal surface } \\
\text { change only }\end{array}$ & $\begin{array}{l}\text { Pus and mucosal } \\
\text { change }\end{array}$ & $\begin{array}{l}\text { Pus-like material } \\
\text { only }\end{array}$ & Total \\
\hline $\begin{array}{l}\text { Minimal-to-moderate congestion } \\
\text { Severe congestion } \\
\text { Severe congestion and haemorrhage } \\
\text { Pus-like material } \\
\text { Total }\end{array}$ & $\begin{aligned} 18 & (5) \\
3 & (3 \neq) \\
0 & (0) \\
0 & \\
21 & (8)\end{aligned}$ & $\begin{aligned} 10 & \left(3^{\S}\right) \\
11 & (11+) \\
4 & \left(4^{*}\right) \\
0 & \\
25 & (18)\end{aligned}$ & $\begin{array}{rr}0 & \\
0 & \\
0 & \\
31 & (8) \\
31 & (8)\end{array}$ & $\begin{array}{rr}28 & (8) \\
14 & (14) \\
4 & (4) \\
31 & (8) \\
77 & (34)\end{array}$ \\
\hline
\end{tabular}

* Two of the four patients culture-positive for HSV

t One of 11 patients culture-positive for HSV

₹ One of three patients culture-positive for HSV

$\S$ One of three patients culture-positive for HSV

TABLE III Clinical details of the five patients with proctitis and rectal HSV

\begin{tabular}{|c|c|c|c|c|c|c|c|}
\hline \multirow[b]{2}{*}{ Patient No } & \multirow{2}{*}{$\begin{array}{l}\text { Last passive } \\
\text { intercourse } \\
\text { (days) }\end{array}$} & \multirow{2}{*}{$\begin{array}{l}\text { No of contacts } \\
\text { in previous } \\
4 \text { weeks }\end{array}$} & \multirow[b]{2}{*}{$\begin{array}{l}\text { Previous HSV } \\
\text { infection }\end{array}$} & \multirow[b]{2}{*}{ Symptoms } & \multirow[b]{2}{*}{ Anal lesions } & \multicolumn{2}{|c|}{ Mucosal appearance } \\
\hline & & & & & & Naked eye & $\begin{array}{l}\times 25 \\
\text { magnification }\end{array}$ \\
\hline 1 & 9 & 1 & $\begin{array}{l}\text { Oral "cold } \\
\text { sore" } 4 \\
\text { months before }\end{array}$ & $\begin{array}{l}\text { Anorectal } \\
\text { soreness/loose } \\
\text { motions }\end{array}$ & Ulcers & Congestion & $\begin{array}{l}\mathrm{H} \\
\mathrm{SC} \\
\mathrm{P}\end{array}$ \\
\hline 2 & 9 & 2 & & $\begin{array}{l}\text { Anorectal } \\
\text { discharge }\end{array}$ & $\begin{array}{l}\text { Ulcers } \\
\text { unnoticed by } \\
\text { patient }\end{array}$ & $\begin{array}{l}\text { Congestion } \\
\text { and pus }\end{array}$ & $\begin{array}{l}\mathrm{H} \\
\mathrm{SC} \\
\mathrm{P}\end{array}$ \\
\hline 3 & 1 & 1 & & $\begin{array}{l}\text { Anorectal } \\
\text { soreness and } \\
\text { discharge/ } \\
\text { loose motions }\end{array}$ & Ulcers & Congestion & $\begin{array}{l}\mathrm{SC} \\
\mathrm{P}\end{array}$ \\
\hline 4 & 7 & 4 & & Asymptomatic & None & Congestion & $\mathrm{SC}$ \\
\hline 5 & 4 & 2 & & Asymptomatic & None & Normal & $\begin{array}{l}\mathrm{MC} \\
\mathrm{P}\end{array}$ \\
\hline
\end{tabular}

$\mathbf{H}=$ Haemorrhagic areas

MC $=$ Minimal-to-moderate congestion

$\mathrm{SC}=$ Severe congestion

$P=$ Pus

TABLE IV Laboratory results of the five patients with proctitis and rectal $H S V$

\begin{tabular}{|c|c|c|c|c|}
\hline \multirow{2}{*}{$\begin{array}{l}\text { Patient } \\
\text { No }\end{array}$} & \multirow[b]{2}{*}{ HSV type } & \multicolumn{2}{|c|}{ HSVCFT titre } & \multirow{2}{*}{$\begin{array}{l}\text { Time taken for } \\
\text { mucosa to } \\
\text { return to } \\
\text { normal (weeks) }\end{array}$} \\
\hline & & Initial & Convalescent* & \\
\hline $\begin{array}{l}1 \\
2 \\
3 \\
4 \\
5\end{array}$ & $\begin{array}{l}2 \\
1 \\
1 \\
\text { Untyped } \\
\text { Untyped }\end{array}$ & $\begin{array}{l}1 / 10 \\
1 / 10 \\
1 / 10 \\
1 / 20 \\
1 / 80\end{array}$ & $\begin{array}{l}1 / 160(2) \\
1 / 20(2) \\
1 / 80(2) \\
1 / 10(2) \\
\text { Unavailable }+\end{array}$ & $\begin{array}{l}7 \\
4 \\
3 \\
3 \\
\text { Unknown }\end{array}$ \\
\hline
\end{tabular}

* Time (in months) from initial visit given in brackets + Patient defaulted

\section{References}

1. King A, Nicol C. Venereal Diseases. 3rd ed. London. Baillière and Tindall. 1975.

2. Goldmeier D, Bateman JRM, and Rodin P. Urinary retention and intestinal obstruction associated with anorectal herpes simplex virus infection. Br Med J 1975; 1: 425-6.

3. Jacobs $\mathbf{E}$. Anal infections caused by herpes simplex virus. $D$ is Colon Rectum 1976; 19: 151-7.

4. Goldmeier D. A study of non-specific proctitis in homosexual men. University of London M D Thesis 1976: 70-8.

5. Rattray MC, Corey L, Reeves WC, Vontver LA, Holmes KK. Recurrent genital herpes among women-symptomatic vs asymptomatic viral shedding. $\mathrm{Br} J$ Vener Dis 1978; 54: 262-5. 